\title{
Cash and Ownership on Firms' Market Value: Evidence from Greek Panel Data
}

\author{
Stavros E. Arvanitis ${ }^{1}$, Theodoros V. Stamatopoulos ${ }^{2}$, Maria Chatzimarkaki $^{3}$
}

\begin{abstract}
:
We implement panel data econometrics on non-linear empirical models to investigate how the firms' market value is related with cash holdings and ownership concentration, on nonfinancial listed companies in Greece, before (2000-2009) and during the Eurozone crisis 20102015 .

It is confirmed the existence of an optimum level of cash (CASH) and the top 5 major shareholders ownership (OWN5) at which firms' return on equity (ROE) has been maximized (concave function), especially over the crisis period and the total one. Yet, a convex function of the Tobin's $Q$ ratio $(Q)$ on $O W N 5$ has also been revealed significant for all sample periods.

The findings support the tradeoff theory and the new kind of agency cost literature on expropriation effects of the minority by the majority. Interaction terms have also been found statistically significant, confirming that the special context of the Eurozone has influenced business, in the narrow Athens Stock Exchange (ASE).

The estimated averages that maximize firms' market values (for instance ROE), in relation to either CASH (0.83 of net assets, during the whole sample period 2000-'15, while 0.77 in the crisis one 2010-'15) or OWN5 (0.10 of equity, during 2000-'15, while 0.36 in the crisis one 2010-'15) could be useful for both investors and policy makers in Greece, a member-country of "sui generis" Eurozone, with an unsustainable public debt.
\end{abstract}

Keywords: Corporate finance, Cash management, Corporate ownership concentration, Agency theory, Expropriation effects, Tradeoff theory.

\footnotetext{
${ }^{1}$ Associate Professor, Technological Educational Institute -T.E.I. of Crete, E-mail: starvan@staff.teicrete.gr

${ }^{2}$ Corresponding author: Professor, Technological Educational Institute -T.E.I. of Crete, Email: stamth@staff.teicrete.gr

${ }^{3}$ Technological Educational Institute -T.E.I. of Crete, E-mail: maria_xatzim@hotmail.com
} 


\section{Introduction}

This paper explores the relationship between efficiency and cash holdings as well as ownership concentration of Greek non-financial listed firms in the Athens Stock Exchange (ASE), during 2000-2015. Based on non-linear effects of cash and ownership on efficiency and examining their implications depended on the sampled sub-periods before or after 2010, when the outbreak of the crisis, of the Greek public debt or in general that one of the Economic and Monetary Union of the European Union (EMU or Eurozone) (Gibson et al., 2014).

The motivation of using efficiency functions on both cash and ownership comes from the hypothesis "the radical macro-economic changes done in Greece during its course on the Eurozone, 2000-2015, should be reflected to the business microeconomic level too". This route resulted, firstly, in liquidity crisis, and secondly in inevitably twin crisis of the Greek public debt and the banking one (Provopoulos, 2014; De Grauwe, 2011). The huge capital inflows to the country, since its accession into the EMU up to the burst of the crisis (2000-2009), invested in the ASE, widely spread the ownership of the Greek listed firms, while the leveraged economic growth, has challenged higher business returns and accompanied with respective liquidity.

The opposite picture has been observed the crisis-period 2010-2015. Market discipline hypothesis (Lane, 1993) did not really work, because both the market interest's punishment put country's solvency at risk and the responsiveness of EUGreek governing has made the sovereign debt un-sustainable [i] (IMF, 2017; IMF, 2010), "aggravating the very illness it is supposed to cure" (Rommerskirchen, 2015). Deepening the recession [ii] has provoked important business losses and decreased liquidity [iii] as well, while massive capital outflows ${ }^{\mathrm{i}}{ }^{\mathrm{i}}$ ] have contributed to ownership concentration.

These macro-economic trends are come true with the study's dataset concerning both the ownership concentration and cash holdings as can be seen in descriptive statistics of Table 2. However, methodologically, this paper considers the macroeconomic framework to be exogenous, with two distinct sub-periods, growth and recession (or more precisely "depression"), with the landmark in 2010, the same year of launching and starting of the European-Greek responsiveness to the Greek sovereign debt crisis (Thalassinos et al., 2015a; 2015b; Thalassinos and Stamatopoulos, 2105).

The relevant finance literature on corporate cash holdings management (MartinezSola et al., 2013) assumes that managers, either, follow a partial adjustment mechanism to reach a target cash level theoretically existed, or seek to improve marginal value of cash for shareholders, depending on different circumstances of business environment, e.g., firm-specific and time-varying information asymmetry or investment opportunities or quality of management or institutional conditions 
related to investors' protection or corporate financial management (Drobetz et al., 2010; Pinkowitz and Williamson, 2007; Dittmar and Martin-Smith, 2007; Pinkowitz et al., 2006; Faulkender and Wang, 2006; Liapis et al., 2013; Thalassinos and Politis, 2011). In ownership concentration literature on the doubtful impact of management in firm's wealth maximization (Alimehmeti and Paletta, 2012; Ameer, 2012), the agency theory prevails, yet with its opposite hypotheses (hypo). The "alignment hypo." considers that high managerial ownership and good internal governance are positive factors on firm valuation, because, when managers align their interests with shareholders, agency costs fall, raising firm's ability for external finance and decreasing the need of cash accumulation (Jensen and Murphy, 1990).

Nevertheless, the "retrenchment hypo." predicts that higher ownership gives more power to managers who can resist on willing of outside shareholders (Berle and Means, 1933; Ozkan and Ozkan, 2004). Reinforcing no systematic relation between ownership structure and firm value other studies find non-monotonic relationship (Morck et al., 1988) or inverse function, that is, profit-maximizing interests of shareholders may cause ownership concentration (Demsetz and Villalonga, 2001).

The paper makes two contributions to the finance literature. First, it discusses both "cash and ownership" factors of the market values of listed firms, justified by the special case of Greece, and time span of the sample. Second, the panel data estimations of the last two drivers, using Greek data and sample period 2000-2015, it is the first time presented to the literature.

Thus, the article considers non-linear relationships (concaves) between either cash holdings or ownership structure and firm value, addressing the general question: in this special context of Greece within the Eurozone 2000-2015, how are cash holdings and ownership concentration related with market valuation of listed firms in the ASE? The latter is elaborated in two research hypotheses to be tested econometrically. The results are mixed and interesting. It is confirmed that the sample data is consistent with a concave function of return on equity $(R O E)$ on cash holdings during both the whole sample period 2000-2015 and sovereign debt crisis 2010-2015, while on ownership structure is true, only in the latter one 2010-2015.

The same pattern, of concave function of the Tobin's Q ratio $(Q)$ on cash holdings has also been confirmed statistically for the study's sample (2000-2015, and 20102015). Nevertheless, the data are consistent with a convex function of $Q$ on ownership (for all three periods, 2000-'15, 2000-'09 and 2010-'15), indicating that the "inverse optimal" level get minimized $Q$ value, and after that, increasing concentration of owners raises efficiency, as measured by $Q$. In almost all estimated empirical models' interaction terms such as "leverage and 2010-'15 crisis period" or "firm's size growth and 2010-'15 crisis period" have been proved statistically significant, confirming that this special economic and political context has seriously influenced business adjustment, in the ASE listed firms. 
The paper is structured as follows: in the next section it is briefly reviewed relevant literature. In section 3 it is derived the research hypotheses, the data and methodology chosen, as well as, the empirical models to be used to test econometrically the question. Section 4 reports and discusses the results, while main conclusions and implications of the study conclude the article.

\section{Relevant literature review}

In an efficient or perfect market of the textbook there is no need of liquidity management because the external finance is always available at equilibrium market prices. That is, the capital allocation in cash or equivalent assets would not affect firm's market valuation (Opler et al., 2001; Stiglitz, 1974).

However, market imperfections imply that financial management balances costs and benefits of holding cash, that is, it matters for shareholders' wealth. Transactional and precautionary motives for hoarding cash from the firms are among the benefits well known from Keynes early as 1936. The transactional motif arises from the operation expenses to cover company's turnover or enable firms to make diversifying acquisitions, while precautionary one may result by undertaking valuable projects when they arise or avoid distress costs when the firms face adverse cash flow shocks.

Nevertheless, cash holdings imply not only an opportunity cost but in addition, raise agency problems because free cash flows give managers discretionary power over shareholders' interests (Jensen, 1986). Likewise, higher cash holdings may have a cost-of-curry, i.e., the difference between debit interest to finance an additional unit of currency and return on hoarding cash, or avoid external financing that could result in the additional cost associated to the lack of monitoring firms from the markets (Dittmar et al., 2003; Jensen and Meckling, 1976)

Depending on firm-specific characteristics, information asymmetry between demand and supply of external funds often results in adverse selection of capital allocation, which would imply underinvestment because it may pass up a project of positive net present value (NPV), as corporations do not desire to issue under valuated securities. On the other hand, higher cash holdings, reducing external funding dependence, would offer to managers more "degrees of freedom" to overtake value-enhanced investments which could refuse it, otherwise. The latter is also invoked by the free cash flow theory (Faulkender and Wang, 2006; Dosoung and Sangsoo, 1997; Jensen, 1986; Myers, 1977).

Thus, trade-off between benefits and costs of cash holdings may cause an optimum level such as the model of Kim et al. (1998) predicts. The latter is in line with agency theory's literature where cash accumulation is not uniformly beneficial (DeAngelo and DeAngelo, 2007; Luo and Hachiya, 2005; Lee et al., 2004; Myers and Majluf, 1984). 
The relationship between firm economic performance and ownership structure is also a topic of great interest in the literature, either in strategic management (Demsetz and Villalonga, 2001; Li and Simerly, 1998; Bethel and Liebeskind, 1993; Oswald and Jahera, 1991) or corporate governance (Shleifer and Vishny, 1986) or agency theory (Thomsen and Pedersen, 2000; La Porta, Lopez-de-Silanes, and Shleifer, 1999; Hill and Snell, 1989; Fama and Jensen, 1983; Amihud and Lev, 1981; Jensen and Meckling, 1976).

Generally, the literature predicts a positive or concave function of firms' market value on ownership concentration. However, there is also a research stream which suggests the inverse function as true, i.e., that ownership structure may be influenced by firm's efficiency, and not vice versa (Chang, 2003; Demsetz and Lehn, 1985; Demsetz, 1983).

Thus, in the logic of agency cost literature, financial and reputational benefits of managers in product or market diversification and fast corporate growth by nonrelated mergers and acquisitions, which provide them with risk reduction, preference of expenses or empire building, are facilitated by widely-held firm's ownership. Equivalently, lower ownership concentration provides lower control of management which could not follow owners' interest in maximizing firm's market value. That is, large shareholders may act as "controlling mechanism" by monitoring managers and preventing "free riding". So, their control is negatively related to diversification strategy since opposed to large shareholders' wealth maximization.

This analysis consistent with the upward part of the concave function "firm's market value-ownership concentration" has an upper limit, economically understandable, when managers become entrenched and start expropriating minority shareholders' wealth. Thus, the literature has suggested another kind of the agency problem, consistent especially with European markets, the conflict "controlling owners vs. minority shareholders" instead of the traditional "ownership vs. management".

Despite this long debate, there is no empirical evidence on the effects of both cash holdings and ownership concentration on firms' market value in Europe and especially in country-members of the EMU under an ongoing sovereign debt crisis. This paper aims to fill this gap. Alimehmeti and Paletta (2012) investigated the relationship "return on assets (ROA) - ownership concentration" for listed firms in Italy before Eurozone crisis (2006-'09). This work in conjunction with those of Ameer's (2012) and Martinez-Sola's et al. (2013) are the more relevant for the present study. Thus, it is provided a summary of them in Table 1.

Table 1. Summary of selected relevant literature

\begin{tabular}{|c|c|c|c|}
\hline Authors & $\begin{array}{c}\text { Relevant } \\
\text { theory/ } \\
\text { Depend. vars./ }\end{array}$ & Sample Data & $\begin{array}{c}\text { Independent vars. } \\
\text { (Significance: + pos., - neg., } \pm\end{array}$ \\
\hline
\end{tabular}




\begin{tabular}{|c|c|c|c|}
\hline & Methods. & & fuzzy, Not Signif.) \\
\hline $\begin{array}{l}\text { Martinez- } \\
\text { Sola et al., } \\
(2013)\end{array}$ & $\begin{array}{l}\text { Agency theory, } \\
\text { Corporate } \\
\text { Finance } \\
\text { theory, Trade- } \\
\text { off theory / } \\
\text { market value } \\
\text { of the firm / } \\
\text { GMM panel } \\
\text { data estimation }\end{array}$ & $\begin{array}{l}\text { Obs=3055, N=472 } \\
\text { US industrial firms, } \\
\mathrm{T}=7 \text { years (2001- } \\
07), \mathrm{K}=5 \\
\text { independent vars., } \\
\text { Source: Osiris } \\
\text { database }\end{array}$ & $\begin{array}{l}\text { (Firm Value: Q, Market-to-Book1, } \\
\text { Market-to-Book2) } \\
\begin{aligned} \text { 1. } & \text { Cash }(+),(+),(+) \\
\text { 2. } & \text { Cash }^{2}(-),(-),(-) \\
\text { 3. } & \text { Intangible }(-),(-),(-) \\
\text { 4. } & \text { Size }(-),(-),(-) \\
\text { 5. } & \text { Leverage }(+),(+),(+)\end{aligned}\end{array}$ \\
\hline $\begin{array}{l}\text { Ameer } \\
(2012)\end{array}$ & $\begin{array}{l}\text { Agency theory } \\
\text { / Tobin's Q } \\
\text { ratio, market } \\
\text { value of the } \\
\text { firm / GMM } \\
\text { panel data } \\
\text { estimation }\end{array}$ & $\begin{array}{l}\text { Obs }=1345, \mathrm{~N}=389 \\
\text { non-finance. } \\
\text { Australian listed } \\
\text { firms, } \mathrm{T}=11 \text { years } \\
(1995-2005), \mathrm{K}=11 \\
\text { independent vars., } \\
\text { Source: } \\
\text { Worldscope }\end{array}$ & 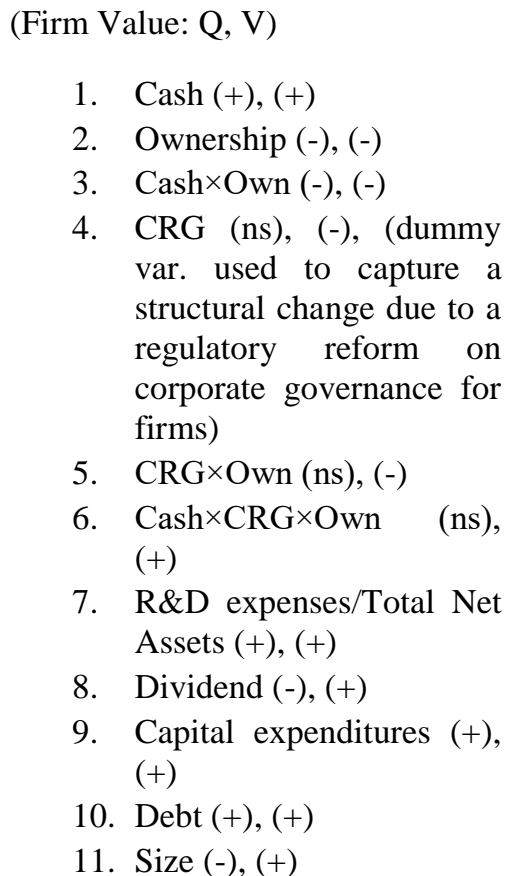 \\
\hline $\begin{array}{l}\text { Alimehmeti } \\
\text { and Paletta } \\
\text { (2012) }\end{array}$ & $\begin{array}{l}\text { Agency theory } \\
\text { / ROA / OLS } \\
\text { regression, } \\
\text { cross section } \\
\text { data }\end{array}$ & $\begin{array}{l}\text { Obs/year: } \\
186 / 2006, \\
201 / 2007, \\
188 / 2008, \\
224 / 2009, \mathrm{~N}=203 \\
\text { Italian listed firms, } \\
\text { T=4 years, K=4 } \\
\text { independent vars., } \\
\text { Source: Amadeus }\end{array}$ & $\begin{aligned} \text { Years: } & 2006, \text { '07, '08, '09. } \\
\text { 1. } & \text { Own. concentration (NS), } \\
& (\mathrm{NS}),(+),(\mathrm{NS}) \\
\text { 2. } & \text { Own. Concentration } \\
& (\mathrm{NS}),(\mathrm{NS}),(-),(\mathrm{NS}) \\
\text { 3. } & \text { Leverage }(+),(\mathrm{NS}),(\mathrm{NS}), \\
& (+) \\
\text { 4. } & \text { Size }(+),(+),(+),(+)\end{aligned}$ \\
\hline
\end{tabular}




\section{Research hypotheses, data and methodology}

Considering the relevant literature briefly presented in the previous section, and the empirical gap of no evidence on the effects of cash and ownership on firms' market value in Europe, this paper is intended to contribute to the literature filling in this gap. Thus, it is worthwhile to address the question: "In Sui Generis EMU (Eichengreen, 2008) and especially in a country under sovereign debt crisis (Greece, 2000-2015), how are cash holdings and ownership concentration related to the market valuation of listed firms in the ASE? The latter is approximated in this study, as usual in the literature, by the return on equity $(R O E)$ and the Tobin's $\mathrm{Q}$ ratio $(Q)$ measures.

In this paper is expected, based on the financial theory and the special business and economic context of Greece and the Eurozone over the sampled period 2000-2015 that both functions $(R O E, Q)$ should be concave upon cash holdings and ownership concentration. This should especially be true over the Eurozone crisis, mainly characterized by consequences of the effective bankruptcy of the Greek public sector in 2010. The establishment of austerity policies by the EU-Greek governing to serve the Greek Sovereign Debt $\left[^{\mathrm{V}}\right]$ deepened the crisis, because, at least, the public sector's suppliers couldn't be paid, given that there wasn't demand for its new bond issues.

Gradually private sector couldn't meet its liabilities, given its weak international competitiveness, and the collapse of absorption in domestic markets, because of drastic restrictive policies applied. Several reasons could be the continuous wage cuts ${ }^{[\mathrm{vi}}$ ] or the breakdown of asset prices [ ${ }^{\mathrm{vii}}$ ] due to the trigger of the country risk and the associated huge outflows of invested funds in Greece. Thus, economically supported the first research hypothesis, which should empirically be tested, is:

H1: the relationship between market value of firms (as measured by ROE or $Q)$ and cash holdings as well as ownership concentration is likely to be nonlinear (concave) in the studied sample.

Moreover, the economy's context relevant characteristics should give the shape in the general relationship of the H1. So, the size growth or the leverage level of the sampled firms, independently or interacting with crisis' dummy variable are also expected to support economically a second research hypothesis to be tested:

H2: the relationship between market value of firms (ROE or Q) and cash holdings as well as ownership concentration is likely to be shaped by control variables like size growth or leverage level, independently or interacting with Eurozone's crisis variable, in the present Greek panel dataset. 
The data of the sample have been drawn from Thomson Reuters/Eikon database and refer to basic balance sheets and income statements items. As commonly in the literature (see Table 1) this study uses a panel dataset of non-financial listed firms in the ASE, during 2000-2015. Of the full sample of 217 firms with 3,025 firm-year observations, they are excluded these ones with fewer observations than five consecutive years including both sub-periods. The sample resulted to contain 183 companies representing 1,524 firm-year observations of the unbalanced Greek panel dataset, 2000-2015.

Two proxy variables have been used to measure the dependent variable of market valuation of firms, that of the return on equity $(R O E=$ Net Income before Extra. Items / Total Shareholder's Equity) and the Tobin's $\mathrm{Q}$ ratio $(Q=$ Market Capitalization / Total Asset Value). The key independent variables are the cash holdings $[\mathrm{CASH}=$ Cash \& Short-Term Investments / Net Assets $(=$ Assets - Cash \& Short-Term Investments)] and ownership concentration (OWN5 = the percentage of shares held by the top 5 major shareholders, as a proxy to Ownership Concentration on Common Shares Outstanding). The square values of both the key independent variables, i.e., CASHsq $\left(=C A S H^{2}\right)$ and $O W N 5 s q\left(=O W N 5^{2}\right)$ serve to test the likely of non-linear relationships. The positive or negative part of the expected concave function of $R O E$ or $Q$ on $C A S H$ and $O W N 5$ should be below their optimal levels.

In the empirical models are also included control variables usually referred to the literature, like, the firm size in levels or growth rate $[S I Z E=\ln$ (Net Assets) or $\left.S I Z E g r=S I Z E_{t}-S I Z E_{t-1}\right]$, the leverage $(L E V=$ Total Debt $/$ Total Assets or $L E V 2=$ Total Debt / Market Capitalization), the net working capital $[N W C=($ Current Assets - Current Liabilities - Cash \& Short Term Investments) / Net Assets], the cash flows $[C F=($ EBITDA - Interest Expense On Debt - Income Taxes - Dividends Per Share) / Net Assets], the market to book value ratio $[M T O B=($ Market Capitalization $/$ Total Shareholder's Equity], and the dividends $[D I V=$ Common Dividends (Cash) $/$ Net Assets].

To test the second research hypothesis, they were constructed the interaction terms, LEVERAGE x CRISIS (LEVCRISIS = LEV x dcrisis) where dcrisis is a dummy variable equals 1 when time $t \geq 2010$ and 0 otherwise, and SIZEgr x CRISIS $($ SIZEgrCRISIS = SIZEgr $\mathrm{x}$ dcrisis $)$.

The implicit assumption for the crisis dummy variable is that it is assumed a structural break in 2010 when Greek government signed the loans offered by the lenders mainly EU partners (European Commission -EC-, European Central Bank ECB-, European Stability Mechanism -ESM-, and International Monetary Fund IMF-), the terms of which have radically changed the conditions of the local markets.

Table 2 presents descriptive statistics for the study's variables distinguishing between the whole sample period 2000-2015 and two sub-periods, i.e., the euphoria 
times 2000-2009 and during the Eurozone crisis 2010-2015. The heterogeneity of the dataset results effortlessly from high dispersion, skewness and kurtosis for almost all variables.

Table 2. Descriptive statistics

Panel A. Pooled data 2000-2015:

\begin{tabular}{|c|c|c|c|c|c|c|c|c|c|c|c|}
\hline Stats & ROE & $Q$ & $\begin{array}{c}C A S \\
H\end{array}$ & $\begin{array}{l}O W \\
N 5\end{array}$ & $L E V$ & $\begin{array}{c}\text { LEV } \\
2\end{array}$ & $\begin{array}{c}S I Z \\
E\end{array}$ & $\begin{array}{c}N W \\
C\end{array}$ & $C F$ & $\begin{array}{c}\text { MTO } \\
B\end{array}$ & DIV \\
\hline $\mathrm{N}$ & $\begin{array}{r}2,85 \\
0\end{array}$ & $\begin{array}{r}2,93 \\
7\end{array}$ & $\begin{array}{r}3,02 \\
5\end{array}$ & $\begin{array}{r}1,97 \\
1\end{array}$ & $\begin{array}{r}3,02 \\
2\end{array}$ & $\begin{array}{r}2,92 \\
7\end{array}$ & $\begin{array}{r}3,02 \\
5\end{array}$ & $\begin{array}{r}3,00 \\
9\end{array}$ & $\begin{array}{r}2,80 \\
4\end{array}$ & $\begin{array}{r}2,75 \\
5\end{array}$ & $\begin{array}{r}3,02 \\
5\end{array}$ \\
\hline Min & $\begin{array}{r}87.7 \\
99\end{array}$ & $\begin{array}{r}0.00 \\
1\end{array}$ & $\begin{array}{r}0.00 \\
0\end{array}$ & & $\begin{array}{r}0.00 \\
0\end{array}$ & $\begin{array}{r}0.00 \\
0\end{array}$ & $\begin{array}{r}13.6 \\
36\end{array}$ & $\begin{array}{r}5.09 \\
1\end{array}$ & $\begin{array}{r}1.73 \\
3\end{array}$ & $\begin{array}{r}0.00 \\
1\end{array}$ & $\begin{array}{r}0.00 \\
0\end{array}$ \\
\hline Max & $\begin{array}{r}31.2 \\
37\end{array}$ & $\begin{array}{r}26.0 \\
39\end{array}$ & $\begin{array}{r}3.27 \\
3\end{array}$ & $\begin{array}{r}0.99 \\
5\end{array}$ & $\begin{array}{r}5.09 \\
5\end{array}$ & $\begin{array}{r}706 . \\
446\end{array}$ & $\begin{array}{r}23.0 \\
51\end{array}$ & $\begin{array}{r}0.75 \\
4\end{array}$ & $\begin{array}{r}0.77 \\
8\end{array}$ & $\begin{array}{r}99.2 \\
10\end{array}$ & $\begin{array}{r}12.6 \\
12\end{array}$ \\
\hline $\mathrm{Sd}$ & $\begin{array}{r}2.23 \\
9\end{array}$ & $\begin{array}{r}1.00 \\
6\end{array}$ & $\begin{array}{r}0.18 \\
8\end{array}$ & $\begin{array}{r}0.27 \\
8\end{array}$ & $\begin{array}{r}0.27 \\
7\end{array}$ & $\begin{array}{r}21.5 \\
22\end{array}$ & $\begin{array}{r}1.42 \\
9\end{array}$ & $\begin{array}{r}0.31 \\
8\end{array}$ & $\begin{array}{r}0.12 \\
5\end{array}$ & $\begin{array}{r}3.77 \\
3\end{array}$ & $\begin{array}{r}0.23 \\
6\end{array}$ \\
\hline Mean & $\begin{array}{r}-\overline{-} \\
0.15 \\
8\end{array}$ & $\begin{array}{r}0.58 \\
5\end{array}$ & $\begin{array}{r}0.10 \\
7\end{array}$ & $\begin{array}{r}0.24 \\
4\end{array}$ & $\begin{array}{r}0.34 \\
1\end{array}$ & $\begin{array}{r}4.28 \\
3\end{array}$ & $\begin{array}{r}18.2 \\
62\end{array}$ & $\begin{array}{r}0.01 \\
6\end{array}$ & $\begin{array}{r}0.01 \\
9\end{array}$ & $\begin{array}{r}1.70 \\
9\end{array}$ & $\begin{array}{r}0.01 \\
8\end{array}$ \\
\hline p50 & $\begin{array}{r}0.02 \\
8\end{array}$ & $\begin{array}{r}0.32 \\
2\end{array}$ & $\begin{array}{r}0.04 \\
6\end{array}$ & $\begin{array}{r}0.10 \\
0\end{array}$ & $\begin{array}{r}0.31 \\
9\end{array}$ & $\begin{array}{r}0.91 \\
9\end{array}$ & $\begin{array}{r}18.1 \\
63\end{array}$ & $\begin{array}{r}0.05 \\
1\end{array}$ & $\begin{array}{r}0.03 \\
2\end{array}$ & $\begin{array}{r}0.93 \\
8\end{array}$ & $\begin{array}{r}0.00 \\
0\end{array}$ \\
\hline $\begin{array}{l}\text { skew } \\
\text { ness }\end{array}$ & $\begin{array}{r}24.5 \\
45\end{array}$ & $\begin{array}{r}12.2 \\
90\end{array}$ & $\begin{array}{r}5.64 \\
4\end{array}$ & $\begin{array}{r}1.01 \\
2\end{array}$ & $\begin{array}{r}4.26 \\
8\end{array}$ & $\begin{array}{r}20.2 \\
92\end{array}$ & $\begin{array}{r}0.26 \\
5\end{array}$ & $\begin{array}{r}3.88 \\
2\end{array}$ & $\begin{array}{r}3.02 \\
7\end{array}$ & $\begin{array}{r}14.5 \\
31\end{array}$ & $\begin{array}{r}50.7 \\
19\end{array}$ \\
\hline $\begin{array}{l}\text { kurtos } \\
\text { is }\end{array}$ & $\begin{array}{r}909 . \\
125\end{array}$ & $\begin{array}{r}265 . \\
239\end{array}$ & $\begin{array}{r}57.7 \\
02\end{array}$ & $\begin{array}{r}2.68 \\
9\end{array}$ & $\begin{array}{r}52.2 \\
10\end{array}$ & $\begin{array}{r}540 . \\
910\end{array}$ & $\begin{array}{r}3.28 \\
2\end{array}$ & $\begin{array}{r}43.0 \\
72\end{array}$ & $\begin{array}{r}32.9 \\
15\end{array}$ & $\begin{array}{r}304 . \\
227\end{array}$ & $\begin{array}{r}2,70 \\
4.17 \\
8\end{array}$ \\
\hline
\end{tabular}

Panel B. Pooled data for the pre-crisis period 2000-2009:

\begin{tabular}{|c|c|c|c|c|c|c|c|c|c|c|c|}
\hline Stats & $R O E$ & $Q$ & $\begin{array}{c}\text { CAS } \\
H\end{array}$ & $\begin{array}{l}O W W \\
N 5\end{array}$ & $\begin{array}{c}L E \\
V\end{array}$ & $\begin{array}{c}\text { LEV } \\
2\end{array}$ & $\begin{array}{c}\text { SIZ } \\
E\end{array}$ & $\begin{array}{c}N W \\
C\end{array}$ & $C F$ & $\begin{array}{c}M T O \\
B\end{array}$ & $D I V$ \\
\hline $\mathrm{N}$ & 1,825 & 1,779 & $\begin{array}{r}1,83 \\
8\end{array}$ & $\begin{array}{r}1,08 \\
0\end{array}$ & $\begin{array}{r}1,8 \\
34\end{array}$ & $\begin{array}{r}1,76 \\
9\end{array}$ & $\begin{array}{r}1,83 \\
8\end{array}$ & $\begin{array}{r}1,8 \\
28\end{array}$ & $\begin{array}{r}1,64 \\
0\end{array}$ & 1,759 & 1,838 \\
\hline Min & $\begin{array}{r}- \\
45.01 \\
3\end{array}$ & 0.016 & $\begin{array}{r}0.00 \\
0\end{array}$ & $\begin{array}{r}0.00 \\
0\end{array}$ & $\begin{array}{r}0.0 \\
00\end{array}$ & $\begin{array}{r}0.00 \\
0\end{array}$ & $\begin{array}{r}13.6 \\
36\end{array}$ & $\begin{array}{r}- \\
1.6 \\
14\end{array}$ & $\begin{array}{r}- \\
1.09 \\
7\end{array}$ & 0.059 & 0.000 \\
\hline
\end{tabular}




\begin{tabular}{|l|r|r|r|r|r|r|r|r|r|r|r|}
\hline Max & 31.23 & 26.03 & 3.27 & 0.97 & 1.4 & 29.2 & 23.0 & 0.7 & 0.77 & 99.21 & 12.612 \\
& 7 & 9 & 3 & 7 & 89 & 03 & 51 & 17 & 8 & 0 & \\
\hline Sd & 1.347 & 1.211 & 0.19 & 0.16 & 0.1 & 2.29 & 1.36 & 0.2 & 0.09 & 4.499 & 0.300 \\
& & & 9 & 6 & 86 & 0 & 0 & 06 & 1 & & \\
\hline Mean & 0.022 & 0.782 & 0.11 & 0.09 & 0.2 & 1.25 & 18.2 & 0.0 & 0.04 & 2.107 & 0.025 \\
& & & 2 & 6 & 89 & 7 & 85 & 89 & 9 & & \\
\hline p50 & 0.052 & 0.502 & 0.04 & 0.03 & 0.2 & 0.56 & 18.2 & 0.0 & 0.04 & 1.232 & 0.005 \\
& & & 8 & 4 & 94 & 4 & 16 & 93 & 5 & & \\
\hline skewn & - & 11.09 & 5.98 & 2.92 & 0.4 & 5.25 & 0.30 & - & - & 12.99 & 40.371 \\
ess & 14.04 & 1 & 3 & 4 & 99 & 9 & 0 & 0.7 & 1.36 & 9 & \\
& 4 & & & & & & & 89 & 0 & & \\
\hline kurtos & 847.0 & 200.7 & 64.2 & 11.9 & 4.6 & 42.7 & 3.29 & 7.2 & 33.6 & 230.4 & $1,691$. \\
is & 80 & 10 & 36 & 27 & 37 & 63 & 2 & 02 & 60 & 18 & 759 \\
\hline
\end{tabular}

Panel C. Pooled data during the crisis-period 2010-2015:

\begin{tabular}{|c|c|c|c|c|c|c|c|c|c|c|c|}
\hline Stats & $R O E$ & $Q$ & $\begin{array}{c}C A S \\
H\end{array}$ & $\begin{array}{l}\text { OW } \\
\text { N5 }\end{array}$ & $L E V$ & $L E V 2$ & $\begin{array}{c}S I Z \\
E\end{array}$ & $\begin{array}{c}N W \\
C\end{array}$ & $C F$ & $\begin{array}{c}M T \\
O B\end{array}$ & $D I V$ \\
\hline $\mathrm{N}$ & 1,025 & $\begin{array}{r}1,15 \\
8\end{array}$ & $\begin{array}{r}1,18 \\
7\end{array}$ & 891 & $\begin{array}{r}1,18 \\
8\end{array}$ & 1,158 & $\begin{array}{r}1,18 \\
7\end{array}$ & $\begin{array}{r}1,18 \\
1\end{array}$ & $\begin{array}{r}1,16 \\
4\end{array}$ & 996 & 1,187 \\
\hline Min & $\begin{array}{r}- \\
87.70 \\
0\end{array}$ & $\begin{array}{r}0.00 \\
1\end{array}$ & $\begin{array}{r}0.00 \\
0\end{array}$ & $\begin{array}{r}0.00 \\
1\end{array}$ & $\begin{array}{r}0.00 \\
0\end{array}$ & 0.000 & $\begin{array}{r}13.7 \\
10\end{array}$ & $\begin{array}{r}- \\
5.09 \\
1\end{array}$ & $\begin{array}{r}- \\
1.73 \\
2\end{array}$ & $\begin{array}{r}0.00 \\
1\end{array}$ & 0.000 \\
\hline Max & 4.082 & $\begin{array}{r}4.46 \\
9\end{array}$ & $\begin{array}{r}1.83 \\
0\end{array}$ & $\begin{array}{r}0.99 \\
5\end{array}$ & $\begin{array}{r}5.09 \\
4\end{array}$ & $\begin{array}{r}706.4 \\
00\end{array}$ & $\begin{array}{r}22.8 \\
30\end{array}$ & $\begin{array}{r}0.75 \\
4\end{array}$ & $\begin{array}{r}0.64 \\
2\end{array}$ & $\begin{array}{r}26.7 \\
40\end{array}$ & 1.202 \\
\hline $\mathrm{Sd}$ & 3.249 & $\begin{array}{r}0.40 \\
3\end{array}$ & $\begin{array}{r}0.16 \\
9\end{array}$ & $\begin{array}{r}0.28 \\
2\end{array}$ & $\begin{array}{r}0.36 \\
3\end{array}$ & $\begin{array}{r}33.58 \\
0\end{array}$ & $\begin{array}{r}1.52 \\
9\end{array}$ & $\begin{array}{r}0.41 \\
4\end{array}$ & $\begin{array}{r}0.15 \\
2\end{array}$ & $\begin{array}{r}1.69 \\
2\end{array}$ & 0.045 \\
\hline Mean & $\begin{array}{r}- \\
0.478\end{array}$ & $\begin{array}{r}0.28 \\
4\end{array}$ & $\begin{array}{r}0.09 \\
9\end{array}$ & $\begin{array}{r}0.42 \\
3\end{array}$ & $\begin{array}{r}0.42 \\
1\end{array}$ & 8.904 & $\begin{array}{r}18.2 \\
25\end{array}$ & $\begin{array}{r}- \\
0.09 \\
7\end{array}$ & $\begin{array}{r}- \\
0.02 \\
4\end{array}$ & $\begin{array}{r}1.00 \\
5\end{array}$ & 0.007 \\
\hline $\mathrm{p} 50$ & $\begin{array}{r}- \\
0.041\end{array}$ & $\begin{array}{r}0.15 \\
9\end{array}$ & $\begin{array}{r}0.04 \\
2\end{array}$ & $\begin{array}{r}0.40 \\
1\end{array}$ & $\begin{array}{r}0.37 \\
3\end{array}$ & 2.295 & $\begin{array}{r}18.1 \\
07\end{array}$ & $\begin{array}{r}- \\
0.01 \\
8\end{array}$ & $\begin{array}{r}0.00 \\
3\end{array}$ & $\begin{array}{r}0.49 \\
3\end{array}$ & 0.000 \\
\hline $\begin{array}{l}\text { skewn } \\
\text { ess }\end{array}$ & $\begin{array}{r}- \\
20.32 \\
7\end{array}$ & $\begin{array}{r}4.19 \\
7\end{array}$ & $\begin{array}{r}4.59 \\
9\end{array}$ & $\begin{array}{r}0.10 \\
4\end{array}$ & $\begin{array}{r}4.23 \\
3\end{array}$ & $\begin{array}{r}13.09 \\
2\end{array}$ & $\begin{array}{r}0.24 \\
0\end{array}$ & $\begin{array}{r}- \\
3.71 \\
8\end{array}$ & $\begin{array}{r}- \\
3.14 \\
4\end{array}$ & $\begin{array}{r}6.72 \\
5\end{array}$ & $\begin{array}{r}19.00 \\
0\end{array}$ \\
\hline
\end{tabular}




\begin{tabular}{|l|r|r|r|r|r|r|r|r|r|r|r|}
\hline kurtos & 518.4 & 28.7 & 32.7 & 1.79 & 40.6 & 223.4 & 3.18 & 33.2 & 26.9 & 75.6 & 459.0 \\
is & 85 & 77 & 14 & 8 & 11 & 52 & 7 & 02 & 16 & 00 & 58 \\
\hline
\end{tabular}

Notes: See section 3 for the definition of the variables.

Given extremely negative skewness and high kurtosis for $R O E$ in either sub-periods, low positive mean (median) value of 2.2\% (5.2\%) during euphoria period 2000-2009 has been proved unsound over the crisis one 2010-2015, when it has been reversed to strongly negative $-47.8 \%(-4.1 \%)$. So totally for the full sample period $2000-2015$ has been turned to negative $-15.8 \%$ on average while slightly positive $2.8 \%$ for the median value.

Nevertheless, the comparison of the aggregate firms' frequency distributions for the Tobin's $Q$ ratio before (2000-2009) and during the crisis (2010-2015) reveals the depth and the extent of the impact of the crisis on the depreciation of their assets, or the redistribution of production capabilities of the Greek economy or even the likely expropriation of minority's ownership from large shareholders. Throughout the whole sample period listed firms remain too much undervalued with a $Q$ mean (median) value of 58\% (32\%) within a framework of high volatility and extreme skewness and kurtosis coefficients, supporting to use the median as the appropriate trend measure.

Although it is much more apparent the gradually trend to approximate from distance normality through the first sample sub-period to the second one, the average (median) value of the stocks of listed firms' in the ASE have fallen to 78\% (50\%) of the replacement cost of their assets before the crisis (2000-2009), while they have collapsed to $28 \%$ (16\%), during the crisis (2010-2015). Table 3 shows the correlation matrix. Among the independent variables it is not observed high pairwise correlations (except $L E V-N W C$ ) supporting the possibility of not having multicollinearity problems.

Table 3. Pairwise Correlations for the pooled data 2000-2015

\begin{tabular}{|c|c|c|c|c|c|c|c|c|c|c|c|}
\hline & ROE & $Q$ & CASH & OWN5 & $L E V$ & LEV2 & SIZE & $N W C$ & $C F$ & $M T O B$ & $\begin{array}{c}D I \\
V\end{array}$ \\
\hline$R O E$ & 1.0000 & & & & & & & & & & \\
\hline$Q$ & $0.0663^{*}$ & 1.0000 & & & & & & & & & \\
\hline $\begin{array}{l}C A S \\
H\end{array}$ & $0.0584^{*}$ & $0.2345^{*}$ & 1.0000 & & & & & & & & \\
\hline $\begin{array}{l}O W \\
N 5\end{array}$ & $0.0555^{*}$ & $0.1451^{*}$ & -0.0326 & 1.0000 & & & & & & & \\
\hline$L E V$ & $0.1302 *$ & $\begin{array}{r}- \\
0.2317^{*}\end{array}$ & $0.2701^{*}$ & $0.2115^{*}$ & 1.0000 & & & & & & \\
\hline$L E V$ & - & - & - & $0.0775 *$ & $0.2486^{*}$ & 1.0000 & & & & & \\
\hline
\end{tabular}




\begin{tabular}{|c|c|c|c|c|c|c|c|c|c|c|c|}
\hline 2 & $0.1405^{*}$ & $0.0998^{*}$ & $0.0705^{*}$ & & & & & & & & \\
\hline SIZE & 0.0072 & $0.1278^{*}$ & $0.0461 *$ & $0.1035^{*}$ & $0.1379^{*}$ & $\begin{array}{r}0.1021 \\
*\end{array}$ & 1.0000 & & & & \\
\hline$N W C$ & $0.1542^{*}$ & 0.0993* & -0.0180 & $0.2221 *$ & $0.6468 *$ & 0.2485 & $0.1343^{*}$ & 1.0000 & & & \\
\hline$C F$ & $0.2099^{*}$ & $0.2020^{*}$ & $0.2587^{*}$ & $0.1941^{*}$ & $0.4448^{*}$ & 0.3028 & $0.1058^{*}$ & $0.4200 *$ & 1.0000 & & \\
\hline $\begin{array}{l}\text { MT } \\
\text { OB }\end{array}$ & $\begin{array}{r}- \\
0.2661^{*}\end{array}$ & $0.6810^{*}$ & $0.0629^{*}$ & $\begin{array}{r}- \\
0.0811^{*}\end{array}$ & 0.0163 & $\begin{array}{r}0.0453 \\
*\end{array}$ & $\begin{array}{r}- \\
0.0735^{*}\end{array}$ & $0.0707^{*}$ & $0.0787 *$ & 1.0000 & \\
\hline DIV & 0.0116 & $0.0777^{*}$ & $0.0905^{*}$ & -0.0327 & $0.0563^{*}$ & -0.0130 & 0.0136 & -0.0062 & $0.1176^{*}$ & $0.0406^{*}$ & $\begin{array}{r}1.0 \\
00 \\
0\end{array}$ \\
\hline
\end{tabular}

Note: See section 3 for the definition of the variables. The asterisk (*) stands for correlation coefficients significant at the $5 \%$ level or better.

For the described dependent variables (ROE or $Q$ ), they are used two models to test empirically if the data are consistent with the above addressed question as it is identified by the relevant research hypotheses. Thus, in the following equation (1) the dependent variable, the market value in firm $(i)$ at time $(t)$, $V_{i t}$, takes the form of $R O E$ in model 1, while that of $Q$ in model 2.

$$
\begin{aligned}
V_{i t}=\beta_{0}+ & \beta_{1} \text { CASH }_{i t}+\beta_{2} \text { CASH }_{i t}^{2}+\beta_{3} \text { OWN }_{i t}+\beta_{4} O W N 5_{i t}^{2}+\beta_{5} \text { LEVCRISIS }_{i t} \\
& +\beta_{6} \text { SIZEgrCRISIS }_{i t}+\beta_{7} \text { SIZEgr }_{i t}+\beta_{8} \text { LEV }_{i t}+\beta_{9} \text { DIV VIt }_{i t} \\
& +\beta_{10} \text { MTOB }_{i t}+\beta_{11} N W C_{i t}+\varepsilon_{i t}
\end{aligned}
$$

It could reasonably be argued that ASE, even after 2002 when the Euro has been launched in Greece, did not manage to get away from a "Thin Market" having high price and volume volatility while low liquidity, claiming the economy attracted in total, nearly zero foreign direct and indirect investments that period. The relevant ratio to GDP was on average 6.5\% net inflows, during 2000-2009, while $-12 \%$ net outflows over the crisis period 2010-2015 [viii].

Thus, it is logical to assume that listed firms in the ASE, throughout the sample period, were considering as priority, among their goals, to maximize the wealth of the shareholders to be able to finance cheap their operations. Hence, because of the nature of the ASE, market value of the listed firms of this sample should be caused by cash and ownership structure, as well as, other control variables presented in equation (1), i.e., it makes sense to assume no-endogeneity problems in this study. 
Consequently, it seems appropriate to use feasible generalized least squares (FGLS) estimators to fit the unbalanced panel-dataset to models 1 for $R O E$ and 2 for $Q$. Moreover, because the sample includes non-financial heterogeneous (from all sectors of the economy) corporations it is logical to expect to have $\operatorname{AR}(1)$ autocorrelation within panels and cross-sectional correlation, as well as, heteroskedasticity across panels. STATA v.12.1 software used, offers these options to meet the sample's needs.

\section{Estimations and Discussion}

Table 4 (or 5 respectively) presents the results of the estimation of model 1 (or 2 respectively) using as proxy of the market value of the firms the ROE (or $Q$ respectively) variable. The concave function of $R O E$ or $Q$ on $C A S H$ is strongly (at $1 \%$ level of statistical significance) confirmed for the full sample period (2000-2015) and during the crisis sub-period (2010-2015), allowing not to reject the first research hypothesis $(\mathrm{HI})$. This means that the increases in cash holdings raise the valuation of listed firms in the ASE up to the optimal level, while after that the opposite happens. Thus, the estimated averages which maximizing firms' market values as measured by ROE (see table 4), in relation to CASH are 0.83 of net assets, during the whole sampled period 2000-'15, while 0.77 in the crisis one 2010-' 15.

The respective figures maximizing ROE in terms of OWN5 are 0.10 of equity, during 2000-' 15 , while 0.36 in the crisis one 2010-' 15 . These estimations could be useful for both investors and policy makers. However, linear and positive statistically significant relationships have been detected between $R O E$ or Tobin's Q ratio $(Q)$ and $C A S H$, for the sub-period 2000-2009. The latter evidence may be understood by the euphoria that was prevailing the first decade of the EMU's common markets existence where all figures had just an upward tendency. Given the outbreak of the global financial crisis (GFC) in 2008, and the resulting credit scarcity (Calomiris and Haber, 2014), the firms seem "to remember" the opportunity cost for money demand (companies' cash holdings), reflected in the estimations through the concave relationships ROE-CASH or Q-CASH over the Eurozone crisis period 2010-2015, where an optimal level of cash holdings makes sense to seek out.

About the expected (HI) concave function of the market (ASE) value of Greek firms on $O W N 5$ (the percentage of shares held by the top 5 major shareholders) it is strongly confirmed statistically significant only for the crisis sub-period (2010-2015) and only if firms' value approximated by the $R O E$ variable. However, $H I$ it is not accepted, for all three sample periods, in the case of the relationship $Q-O W N 5$ which has proved statistically significant but, in contrast of $H l$, here as a convex function.

This, it could be understood based on descriptive statistics (Table 2) for the "replacement cost" variable $Q$ which collapsed in terms of the median value at $16 \%$ in the crisis period, from $50 \%$ respectively during the euphoria one. The latter fact should be considered in combination with respective trend statistics of $O W N 5$, where 
top 5 major investors have many times multiplied their companies' ownership, i.e., from $9.6 \%$ on average (or $3.4 \%$ in median terms) in the $2000-2009$ period, jumped to $42.3 \%(40.1 \%)$ respectively in crisis period $2010-2015$.

In addition, major shareholder's type has changed between two subsequent periods, expressing qualitative changes too, in ownership concentration procedure; in the study's sample, their descending classification, on average became Government Agency 45\% (55\%), (Private Equity, 45\%), Holding Company 41\% (34\%), Corporation $29 \%(30 \%)$ and Individual Investor 22\% (26\%) during 2000-2009 (2010-2015) periods.

So, it may be understood the convex function of $Q$ on $O W N 5$ as an indication of verification to have happened "expropriation effects" for stocks in the ASE which throughout the 16 years sample period were undervalued (trend statistics, $Q<1$ ). Thus, in the first downward slope of this $Q$ function when ownership concentration increases it may be expected a fall in market capitalization until a minimum level (breakpoint) reaches, when new large shareholders take on the management and new era of confidence by the market is gradually restored (translating its upward slope). That is, the new kind of agency cost theory that one which the controlling owners expropriate value from the minority, seems to be consistent with the fit of our data to model 2 (equation 1, with dependent variable the Tobin's Q ratio).

Table 4. Estimations for the Efficiency equations (ROE)

\begin{tabular}{|c|c|c|c|}
\hline VARIABLES & $\begin{array}{c}(1) \\
R O E \\
\text { FGLS Hetero \& psar1 } \\
2000-15 \\
\end{array}$ & $\begin{array}{c}(2) \\
R O E \\
\text { FGLS Hetero \& psar1 } \\
2000-09\end{array}$ & $\begin{array}{c}(3) \\
R O E \\
\text { FGLS Hetero \& psar1 } \\
2010-15 \\
\end{array}$ \\
\hline CASH & $\begin{array}{c}0.710 * * * \\
(18.96)\end{array}$ & $\begin{array}{c}0.0668 * * \\
(2.262)\end{array}$ & $\begin{array}{c}1.158 * * * \\
(28.13)\end{array}$ \\
\hline CASHsq & $\begin{array}{c}-0.429 * * * \\
(-9.622)\end{array}$ & $\begin{array}{l}-0.0146 \\
(-0.408)\end{array}$ & $\begin{array}{c}-0.753 * * * \\
(-9.876)\end{array}$ \\
\hline OWN5 & $\begin{array}{l}0.0198 \\
(0.745)\end{array}$ & $\begin{array}{l}0.000279 \\
(0.00785)\end{array}$ & $\begin{array}{c}0.0893 * * * \\
(6.408)\end{array}$ \\
\hline OWN5sq & $\begin{array}{c}-0.0951 * * * \\
(-3.096)\end{array}$ & $\begin{array}{l}-0.0271 \\
(-0.494)\end{array}$ & $\begin{array}{c}-0.123 * * * \\
(-6.449)\end{array}$ \\
\hline LEVCRISIS & $\begin{array}{c}-0.420 * * * \\
(-29.11)\end{array}$ & & $\begin{array}{c}-0.349 * * * \\
(-40.22)\end{array}$ \\
\hline SIZEgrCRISIS & $\begin{array}{c}0.743 * * * * \\
(44.32)\end{array}$ & & $\begin{array}{c}0.868 * * * \\
(81.30)\end{array}$ \\
\hline$N W C$ & $\begin{array}{c}0.323 * * * \\
(30.12)\end{array}$ & $\begin{array}{c}0.135 * * * \\
(12.37)\end{array}$ & $\begin{array}{c}0.547 * * * \\
(46.37)\end{array}$ \\
\hline$M T O B$ & $\begin{array}{c}0.00508 * * \\
(2.401)\end{array}$ & $\begin{array}{c}0.0260 * * * \\
(13.81)\end{array}$ & $\begin{array}{c}-0.112 * * * \\
(-24.21)\end{array}$ \\
\hline$D I V$ & $\begin{array}{c}0.863 * * * * \\
(6.587)\end{array}$ & $\begin{array}{c}1.143 * * * \\
(11.11)\end{array}$ & $\begin{array}{c}0.847 * * * \\
(4.509)\end{array}$ \\
\hline LEV2 & & $-0.0185^{* * *}$ & \\
\hline
\end{tabular}




\begin{tabular}{lccc} 
& & $(-13.73)$ & \\
SIZEgr & & $0.0868^{* * *}$ & \\
& & $(11.66)$ & \\
Constant & $-0.0651^{* * *}$ & $-0.0106^{* *}$ & $-0.0465^{* * *}$ \\
& $(-16.49)$ & $(-2.230)$ & $(-8.615)$ \\
& & & 671 \\
Observations & 1,524 & 818 & 164 \\
Number of id & 183 & 133 & \\
\hline
\end{tabular}

Table 5. Estimations for the Efficiency equations (Tobin's $Q$ ratio)

\begin{tabular}{|c|c|c|c|}
\hline VARIABLES & $\begin{array}{c}(4) \\
Q \\
\text { FGLS Hetero \& psar1 } \\
2000-15 \\
\end{array}$ & $\begin{array}{c}\text { (5) } \\
Q \\
\text { FGLS Hetero \& psar1 } \\
2000-09 \\
\end{array}$ & $\begin{array}{c}(6) \\
Q \\
\text { FGLS Hetero \& psar1 } \\
2010-15 \\
\end{array}$ \\
\hline CASH & $\begin{array}{c}0.851 * * * \\
(8.776)\end{array}$ & $\begin{array}{c}0.971 * * * \\
(9.475)\end{array}$ & $\begin{array}{c}0.262 * * * \\
(6.338)\end{array}$ \\
\hline CASHsq & $\begin{array}{c}-0.435^{* * *} \\
(-4.374)\end{array}$ & $\begin{array}{c}0.155 \\
(0.703)\end{array}$ & $\begin{array}{c}-0.290 * * * \\
(-7.165)\end{array}$ \\
\hline OWN5 & $\begin{array}{c}-0.500 * * * \\
(-7.760)\end{array}$ & $\begin{array}{c}-0.327 * * \\
(-2.444)\end{array}$ & $\begin{array}{c}-0.224 * * * \\
(-7.779)\end{array}$ \\
\hline$O W N 5 s q$ & $\begin{array}{c}0.437 * * * \\
(6.178)\end{array}$ & $\begin{array}{c}0.448 * * \\
(2.280)\end{array}$ & $\begin{array}{c}0.235^{* * *} * \\
(7.592)\end{array}$ \\
\hline LEVCRISIS & $\begin{array}{c}-0.386^{* * *} * \\
(-12.19)\end{array}$ & & $\begin{array}{c}-0.464 * * * \\
(-21.77)\end{array}$ \\
\hline SIZEgrCRISIS & $\begin{array}{c}-0.00874 \\
(-0.379)\end{array}$ & & $\begin{array}{c}-0.0801 * * * \\
(-11.17)\end{array}$ \\
\hline$N W C$ & $\begin{array}{c}0.155^{* * * *} \\
(4.536)\end{array}$ & $\begin{array}{c}0.341 * * * \\
(7.837)\end{array}$ & $\begin{array}{c}0.0477 * * * \\
(5.394)\end{array}$ \\
\hline$D I V$ & $\begin{array}{c}5.420 * * * \\
(13.03)\end{array}$ & $\begin{array}{c}5.474 * * * \\
(13.80)\end{array}$ & $\begin{array}{c}3.547 * * * \\
(19.84)\end{array}$ \\
\hline$L E V 2$ & & $\begin{array}{c}-0.0965 * * * \\
(-20.14)\end{array}$ & \\
\hline SIZEgr & & $\begin{array}{c}0.113 * * * \\
(4.053)\end{array}$ & \\
\hline Constant & $\begin{array}{c}0.442 * * * \\
(29.29)\end{array}$ & $\begin{array}{c}0.583 * * * \\
(41.90)\end{array}$ & $\begin{array}{c}0.439 * * * \\
(33.17)\end{array}$ \\
\hline Observations & 1,524 & 818 & 671 \\
\hline Number of id & 183 & 133 & 164 \\
\hline
\end{tabular}

$z$-statistics in parentheses

$* * * p<0.01, * * p<0.05, * p<0.1$

Notes: See section 3 for the definition of the variables. Blocked Adaptive Computationally Efficient Outlier Nominators (BACON) algorithm proposed by Billor, Hadi, and Velleman (2000), has been applied to the whole set of dependent and explanatory variables used in estimations presented in both Tables 4 and 5. The 5th percentile (percentile=0.05) of the chisquared distribution has been used as a large enough threshold to separate outliers from nonoutliers, and remove them from the final estimations. The routine is offered by STATA v.12.1 we have used. 
Likewise, in almost all estimated empirical models, the interaction terms "leverage" (LEV) or "firm's size growth" (SIZEgr) associated with the dummy for the "crisis sub-period 2010-2015" (dcrisis) have been proven statistically significant. This evidence could be understood as that the special economic and political context of the Eurozone crisis has seriously influenced business adjustment in the ASE listed firms. In other words, no matter what $R O E$ or $Q$ it is used as the dependent variable, the good fit of the sample data on equation 1 it seems to allow not rejecting the second research hypothesis $(H 2)$.

Regarding to control variables, net working capital (NWC) appears strongly statistically significant in both estimated models $(R O E, Q)$ and as it is expected with higher (lower) coefficient in turbulent times of 2010-2015 for $R O E(Q)$ function. Dividends $(D I V)$ variable has also been found statistically significant in both estimated models ( $R O E$ and $Q$ ) and as it was expected with lower positive coefficients in the crisis sub-period.

The study verifies Demsetz and Villalonga's (2001) evidence for non-significance of the SIZE variable on market firm valuation [ $\left.{ }^{\mathrm{i}}\right]$. For this reason, it is entered the growth rate of this variable (SIZEgr) in the models which has proved statistically significant and positively related to both $R O E$ and $Q$ functions, during the pre-crisis period (2000-2009) [x]. As it is concern, market to book value (MTOB), its use makes sense only in the first model of $R O E$, as $Q$ has the same nominator with it. It has proved the economically expected positive estimation for the euphoria period 2000-'09, while negative for the crisis one.

The latter may be understood from the market faith on listed firms in the ASE that gives a tolerance period in negative returns of companies, believed that it is mainly due to the negative political environment, producing country risk. This evidence is consistent with trend statistics in Table 2 and moreover with pairwise correlations of Table 3. Finally, the leverage variable (LEV2) is used only in first sub-period 20002009, because its other version enters interacting with the dummy of crisis (dcrisis) in the rest periods. Q-LEV2 should have a negative correlation as it can be seen by the relative statistically significant pairwise respective coefficient in Table 3, which is confirmed by the respective negative coefficient in the relevant model 2 (Table 5).

\section{Conclusions}

The paper explores the relationship between market value of non-financial listed firms in the Athens Stock Exchange (ASE) and cash holdings as well as ownership concentration. The question is specified in two research hypotheses concerning these determinants while including the interactions terms leverage or firms' size growth associated with Eurozone crisis.

As far as it is known it is the first time that these two independents ( $C A S H$ and $O W N 5)$ are used to test nonlinear relations of $R O E$ or Tobin's $\mathrm{Q}$ ratio $(Q)$. In 
addition, the latter is tested for Greek panel data and time period 2000-2015, including the ongoing crisis (2010-2015). So, this article contributes to the literature by filling in the gap of no empirical evidence on European data especially during the crisis.

The effective sample of 183 listed non-financial companies contains about 1,524 firm-year observations of the unbalanced Greek panel dataset, 2000-2015. The full sample split in two sub-periods (2000-2009 and 2010-2015), with the breakpoint in 2010. The latter it is justified by accepting the effective bankruptcy of the Greek public sector in that year, as the major event of an inevitable crisis of weak internationally competitive production, that altered the economic history of the country (Bank of Greece, 2106).

Because of the "Narrow Market" in Greece (ASE), it is logical to assume that the market value of the listed firms of the sample should be caused by cash and ownership structure, as well as, other control variables of course, some of them presented in the estimated equation (1). Thus, it makes sense to ssume noendogeneity problems in this study, which allowed having used feasible generalized least squares (FGLS) estimators to the proposed panel data empirical models.

The findings are interesting and mixed compared to the literature. The concave function of $R O E$ or $Q$ on $C A S H$ is strongly confirmed for the full sample period (2000-2015) and during the crisis sub-period (2010-2015) too, allowing not having rejected the first research hypothesis $(H 1)$. At the same time, it is provided empirical support to the tradeoff theory which suggests an optimum cash level maximizing firms' market value. However, linear and positive statistically significant relationship between $R O E$ or $Q$ and $C A S H$ has been revealed for the first sub-period 2000-2009. This deviation from nonlinearity may be understood by the euphoria that prevailed the first decade of EMU markets, when all figures had just an upward tendency.

Nevertheless, the expected $(\mathrm{HI})$ concave function of the market value of Greek firms on top 5 major shareholders $(O W N 5)$ is strongly confirmed only for the crisis subperiod (2010-2015) and only if firms' market value approximated by the $R O E$ variable. In contrast, it is not accepted, for all three sample periods, in the case of the relationship $Q-O W N 5$, which the study confirms a convex function. So, the convex function of $Q$ on $O W N 5$ may be understood as an indication having happened "expropriation effects" for stocks in the ASE, which throughout the 16 years sample period were undervalued. Thus, the concave function of firms' value and ownership concentration as well as the associated $H \mathrm{l}$ has only been partly confirmed from this study.

Moreover, the paper provides empirical evidence to the interaction terms of "leverage-crisis" or "firm's size growth-crisis" which both have been proved significant. The special economic and political context of the Eurozone crisis has 
seriously negatively influenced business adjustment in the ASE listed firms, allowing not having rejected the second research hypothesis (H2) on interaction terms, while, it could help in understanding the partial verification of the first hypothesis $(H 1)$ too.

Policy implications are straightforward from the findings of the study. These concern not only managers who have to search for the optimal level of cash and ownership but also control debt and assets in order to attract investors. Both managers and investors could be benefited from the estimated here max points of ROE functions in relation either to $C A S H$ which have been founded to be 0.83 of net assets, during the whole sample period 2000-'15, while 0.77 in the crisis one 2010' 15 , or in the case of $O W N 5$ to be 0.10 of equity, during the sample period, while 0.36 in the crisis one. They also concern EU-Greek policy makers in the perspective to integrate open capital markets in the EMU, as it was the case of ECB Governor's M. Draghi commitment as of 26-7-2012 speech "... Within our mandate, the ECB is ready to do whatever it takes to preserve the euro. And believe me, it will be enough. ..." (Draghi, 2012). Further research needs to be done to verify the evidence of this paper for a larger dataset in the Eurozone, distinguishing South West Euro Area Periphery (Aizenman, et al., 2013) and the Core of EMU members.

\section{References:}

Aizenman, J., Hutchison, M. and Jinjarak, Y. 2013. What is the Risk of European Sovereign Debt Defaults? Fiscal Space, CDS Spread and Market Pricing of Risk. Journal of International Money and Finance, 34(C), 37-59.

Alimehmeti, G. and Paletta, A. 2012. Ownership concentration and effects over firm performance: evidence from Italy. European Scientific Journal, 8(22), 39-49.

Ameer, R. 2012. Impact of cash holdings and ownership concentration on firm valuation: Empirical evidence from Australia. Review of Accounting and Finance, 11(4), 448-467.

Amihud, Y. and Levy, B. 1981. Corporation Risk Reduction as a Managerial Motive for Conglomerate Mergers. The Bell Journal of Economics, 12(2), 605-617.

Bank of Greece, Eurosystem. 2017. Bulletin of conjectural indicators, No.172, 2017 and No.148, 2013. Available at http://www.bankofgreece.gr/BogEkdoseis/sdos20170102.pdf and http://www.bankofgreece.gr/BogEkdoseis/sdos201301-02.pdf.

Bank of Greece, Eurosystem. 2016. Summary of the Annual Report, 2015, Athens. Available at http://www.bankofgreece.gr/BogEkdoseis/Summary_Annrep2015.pdf

Berle, A. and Means, G. 1933. The Modern Corporation and Private Property. New York, Harcourt, Brace, \& World.

Bethel, J.E. and Liebeskind, J. 1993. The effects of ownership structure on corporate restructuring. Strategic Management Journal, 14, Special Issue, Corporate Restructuring, $15-31$.

Calomiris, C.W. and Haber, S.H. 2014. Fragile by Design: The Political Origins of Banking Crises and Scarce Credit. Princeton University Press, Princeton, New Jersey.

Chang, S.J. 2003. Ownership Structure, Expropriation, and Performance of Group Affiliated Companies in Korea. The Academy of Management Journal, 46(2), 238-253.

DeAngelo, H. and DeAngelo, L. 2007. Capital structure, payout policy, and financial flexibility. Working paper, University of Southern California. 
Demsetz, H. 1983. The Structure of Ownership and the Theory of the Firm. Journal of Law and Economics, 26(2), 375-390.

Demsetz, H. and Lehn, K. 1985. The structure of corporate ownership: Causes and consequences. The Journal of Political Economy, 93(6), 1155-1177.

Demsetz, H. and Villalonga, B. 2001. Ownership structure and corporate performance. Journal of Corporate Finance, 7, 209-233.

De Grauwe, P. 2011. The governance of a fragile Eurozone. Working document, CEPS, No. 346.

Dittmar, A., Mahrt-Smith, J. and Servaes, H. 2003. International corporate governance and corporate cash holdings. Journal of Financial and Quantitative Analysis, 38, 111-133.

Dittmar, A. and Mahrt-Smith, J. 2007. Corporate governance and the value of cash holdings. Journal of Financial Economics, 83, 599-634.

Dosoung, C. and Sangsoo, P. 1997. Targeted share repurchases, free cash flows, and shareholder wealth: additional evidence. Managerial Finance, 23(3), 49-63.

Draghi, M. 2012. Introductory statement to the press conference (with Q\&A). Frankfurt, Available at https://www.ecb.europa.eu/press/pressconf/2012/html/is120906.en.html .

Drobetz, W., Gruninger, M. and Hirschvogl, S. 2010. Information asymmetry and the value of cash. Journal of Banking and Finance, 34, 2168-2184.

Eichengreen, B. 2008. Sui generis EMU. Working paper series, NBER, WP13740.

Fama, E.F. and Jensen, M.C. 1983. Separation of Ownership and Control. Journal of Law and Economics, 26(2), 301-325.

Faulkender, M. and Wang, R. 2006. Corporate financial policy and the value of cash holdings. Journal of Finance, 61(4), 1957-1990.

Gibson, H.D., Palivos, T. and Tavlas, G.S. 2014. The crisis in the Euro area: an analytical overview. Journal of Macroeconomics, 39, Part B, 233-239.

Hill, C.W. and Snell, S.A. 1989. Effects of Ownership Structure and Control on Corporate Productivity. The Academy of Management Journal, 32(1), 25-46.

International Monetary Fund (IMF). 2010. IMF country (Greece) report No. 10/372, December 17, 2010. Available at http://www.imf.org/en/Publications/CR/Issues/2016/12/31/Greece-Second-ReviewUnder-the-Stand-By-Arrangement-Staff-Report-Press-Release-on-the-24520 .

International Monetary Fund (IMF). 2017. Press Release No. 17/38, February 6, 2017. Available at http://www.imf.org/en/Publications/CR/Issues/2017/02/07/Greece-2017Article-IV-Consultation-Press-Release-Staff-Report-and-Statement-by-the-44630 .

Jensen, M.C. 1986. Agency cost of free cash flow, corporate finance, and takeovers. The American Economic Review, 76, 323-329.

Jensen, M.C. and Meckling, W.H. 1976. Theory of the firm: Managerial behavior, agency costs and ownership structure. Journal of Financial Economics, 3(4), 305-360.

Jensen, M.C. and Murphy, K.J. 1990. Performance pay and top-management incentives. Journal of Political Economy, 98, 225-264.

Kim, C.S., Mauer, D.C. and Sherman, A.E. 1998. Antecedents of corporate liquidity: theory and evidence. Journal of Financial and Quantitative Analysis, 33, 305-334.

Lane, T. 1993. Market Discipline. IMF Staff Papers, 40(1), 1-30.

La Porta, R., Lopez-de-Silanes, F. and Shleifer, A. 1999. Corporate Ownership around the World. Journal of Finance, 54(2), 471-517.

Lee, P., Stulz, R. and Williamson, R. 2004. Do firms in countries with poor protection of investor rights hold more cash? Working paper, Georgetown University, Washington, DC. 
Li, M. and Simerly, R.L. 1998. The Moderating Effect of Environmental Dynamism on the Ownership and Performance Relationship. Strategic Management Journal, 19(2), 169179.

Liapis, K., Rovolis, A., Galanos, C. and Thalassinos, I.E. 2013. The Clusters of Economic Similarities between EU Countries: A View Under Recent Financial and Debt Crisis. European Research Studies Journal, 16(1), 41-66.

Luo, Q. and Hachiya, T. 2005. Bank relations, cash holdings, and firm value: evidence from Japan. Management Research News, 28(4), 61-74.

Martinez-Sola, C., Garcia-Teruel P.J. and Martinez-Solano, P. 2013. Corporate cash holding and firm value. Applied Economics, 45, 161-170.

Morck, R., Shleifer, A. and Vishny, R. 1988. Management Ownership and Market Valuation: An Empirical Analysis. Journal of Financial Economics, 20, 293-315.

Myers, S.C. 1977. Determinants of corporate borrowing. Journal of Financial Economics, 5, $147-175$.

Myers, S.C. and Majluf, N.S. 1984. Corporate financing and investment decision when firms have information that investors do not have. Journal of Financial Economics, 13(2), 187221.

Opler, T., Pinkowitz, L., Stulz, R. and Williamson, R. 2001. Corporate cash holdings. Journal of Applied Corporate Finance, 14, 55-67.

Oswald, S.L., and Jahera, J.S. 1991. The Influence of Ownership on Performance: An Empirical Study. Strategic Management Journal, 12(4), 321-326.

Ozkan, A. and Ozkan, N. 2004. Corporate cash holdings: an empirical investigation of UK companies. Journal of Banking and Finance, 28(9), 2103-2134.

Pinkowitz, L., Stulz, R. and Williamson, R. 2006. Does the contribution of corporate cash holdings and dividends to firm value depend on governance? A Corporate cash holding and firm value cross-country analysis. Journal of Finance, 61, 2725-2751.

Pinkowitz, L. and Williamson, R. 2007. What is the market value of a dollar of corporate cash? Journal of Applied Corporate Finance, 19, 74-81.

Provopoulos, G. 2014. The Greek Economy and Banking System: Recent Developments and the Way Forward. Journal of Macroeconomics, 39, Part B, 240-249.

Rommerskirchen, C. 2015. Debt and Punishment: Market Discipline in the Eurozone. New Political Economy, 20(5), 752-782.

Shleifer, A., and Vishny, R. 1986. Large shareholders and corporate control. Journal of Political Economy, 94, 461-488.

Stiglitz, J. 1974. On the irrelevance of corporate financial policy. American Economic Review, 64, 851-866.

Thalassinos, I.E. and Politis, D.E. 2011. International Stock Markets: A Co-integration Analysis. European Research Studies Journal, 14(4), 113-129.

Thalassinos, I.E., Stamatopoulos, D.T. and Thalassinos, E.P. 2015a. The European Sovereign Debt Crisis and the Role of Credit Swaps. Chapter book in The WSPC Handbook of Futures Markets (eds) W. T. Ziemba and A.G. Malliaris, in memory of Late Milton Miller (Nobel 1990) World Scientific Handbook in Financial Economic Series Vol. 5, Chapter 20, pp. 605-639, ISBN: 978-981-4566-91-9, (doi: 10.1142/9789814566926_0020).

Thalassinos, I.E., Pintea, M., Raţiu, I.P. 2015b. The Recent Financial Crisis and Its Impact on the Performance Indicators of Selected Countries during the Crisis Period: A Reply. International Journal of Economics and Business Administration, 3(1), 3-20.

Thalassinos, I.E. and Stamatopoulos, V.T. 2015. The Trilemma and the Eurozone: A Pre- 
Announced Tragedy of the Hellenic Debt Crisis. Journal of Economics and Business Administration, 3(3), 27-40.

Thomsen, S. and Pedersen, T. 2000. Ownership Structure and Economic Performance in the Largest European Companies. Strategic Journal Management, 21(6), 689-705.

Zettelmeyer, J., Trebesch, C. and Gulati, M. 2013. The Greek debt restructuring: An autopsy. Economic Policy, 28(75), 513-563.

\footnotetext{
i "Public debt has reached 179 percent (of GDP) at end-2015 and is unsustainable." IMF, Press Release No. 17/38, February 6, 2017, p. 3. Available at http://www.imf.org/en/Publications/CR/Issues/2017/02/07/Greece-2017-Article-IVConsultation-Press-Release-Staff-Report-and-Statement-by-the-44630 . At the end-2009, before the implementation of fiscal adjustment programs by Troika (IMF, EC, ECB)-Greek governing (under memorandums of understanding -MoU-), the Public Debt/GDP ratio was $127 \%$ as it is reported by IMF country (Greece) report No. 10/372, December 17, 2010, p. 59. Available at http://www.imf.org/en/Publications/CR/Issues/2016/12/31/Greece-SecondReview-Under-the-Stand-By-Arrangement-Staff-Report-Press-Release-on-the-24520 ${ }^{i i}$ Real GDP grew on average (with standard deviation) $5.9 \%$ (3.1\%) per year, during the euphoria period 2000-2009, while reduced by $-4.3 \%$ (2.7\%), respectively, during the crisis 2010-2015. Source: Hellenic Statistical Authority, National Accounts, various issues. Available at http://www.statistics.gr/en/statistics/-/publication/SEL15/-

iii Overdrafts offered by the Greek banking system to non-financial domestic corporations were on average (with standard deviation) 23.6 (5.6) billion Euros per year, during the euphoria period 2000-2009, while declined to 18.1 (7.6) billion Euros, over the crisis 20102015. Source: Bank of Greece, Bank deposits and loan interest rates. Available at http://www.bankofgreece.gr/Pages/en/Statistics/rates_markets/deposits.aspx. Credit expansion to private sector (Cumulative Change during period) offered from Monetary Financial Institutions (MFIs) were on average (with standard deviation) 26.9 (10.3) billion Euros, during 2004-2009, while precipitated (actually to “contraction”) to (minus) -6.3 (3.7) billion Euros, during the crisis 2010-2015. Source: Bank of Greece, Bulletin of Conjectural Indicators, various issues. Available at http://www.bankofgreece.gr/Pages/en/Publications/AllItems.aspx?List_ID=7E6B3766BD04-4A45-AF1B-C033A426BD8B\&Year=2016. Finally, a crucial indicator that synthesizes the healthy prospects of all markets of the country, Non-Performing Loans ratio (yearly) in the Greek banking system by the domestic private sector, was on average (with standard deviation) $6.7 \%$ (2.2\%) during 2000-2009, while multiplied to $25.0 \%$ (11.2\%) during the crisis 2010-2015. Source: World Bank. Available at http://data.worldbank.org/indicator/FB.AST.NPER.ZS?locations $=G R$.

${ }^{i v}$ Net inflows (transactions in portfolio investments + financial derivatives) have reached on average (with standard deviation) 12.8 (4.9) billion Euros per year, during the euphoria period 2000-2009, while, turned into net outflows of 19.9 (41.8) billion Euros, during the crisis 2010-2015. Source: Bank of Greece, Bulletin of Conjectural Indicators, various issues. Available at http://www.bankofgreece.gr/Pages/en/Publications/AllItems.aspx?List_ID=7E6B3766BD04-4A45-AF1B-C033A426BD8B\&Year $=2016$.

${ }^{v}$ Greek 10-year bond Yields were on average (with stdev.) $4.7 \%(0.7 \%)$ during the euphoria period 2000-2009, while they climbed up 12.4\% (6.0\%) during the crisis 2010-2015. Source: Bank of Greece, Greek government securities. Available at
} 
http://www.bankofgreece.gr/Pages/en/Statistics/rates_markets/titloieldimosiou/titloieldimosi ou. aspx? Year $=2000$

${ }^{v i}$ Based on European System of National and Regional Accounts (ESA-2010), the Employees' compensation has had a peak value of 84.7 billion Euros in 2009, presenting 93.4\% rise during the period 2000-2009 while precipitated - 32.9\% during the crisis period 2009-2015. Source: Hellenic Statistical Authority/Annual non-financial accounts by institutional sector/Total Economy (S.1) 1995-2015 Available at http://www.statistics.gr/en/statistics/-/publication/SEM91/-

${ }^{v i i}$ Based on European System of National and Regional Accounts (ESA-2010), Total property income (=Interest + Distributed Income of Corporations + Reinvested Earnings on Foreign Direct Investment+ Other investment income+ Rent) had a peak value of 46.9 billion Euros in 2008 (starting year of the Global Financial Crisis), presenting $28.6 \%$ rise during the period 2000-2008 while collapsed - 52.5\% during the crisis period 2008-2015. Source: Hellenic Statistical Authority/Annual non-financial accounts by institutional sector/Total Economy (S.1) 1995-2015. Available at http://www.statistics.gr/en/statistics//publication/SEM91/-

viii Direct plus Indirect foreign investments as a ratio of GDP, had a peak value $9.7 \%$ in 2009 and on average (stdev.) $6.5 \%$ (1.8\%) during the period 2000-2009, while, they plunged to $12.0 \%(20.3 \%)$, over the crisis period 2010-2015. The latter obviously contains the outlier of - 51.8\% of GDP in 2012 of huge outflows, in compliance with so called PSI (private sector involvement) (see Zettelmeyer et al., 2013). Source: Bank of Greece (http://www.bankofgreece.gr/Pages/en/Statistics/externalsector/balance/default.aspx ), for the Greek Balance of Payments data, while, Hellenic Statistical Authority (http://www.statistics.gr/en/statistics/-/publication/SEM91/- ) for the GDP (at current prices and million euros) from National Accounts Statements.

${ }^{i x}$ On previous versions of estimated models not presented here in Tables 4 and 5.

${ }^{x}$ In the other periods SIZEgr it is entered as an interaction with dcrisis, so it cannot be used separately too. 